\title{
Green Economy-Inevitable Economy of the Industrial Revolutionary Period 4.0
}

\section{Tran Ngoc Son}

Tomas Bata University, Czech Republic

"Corresponding author: Tran Ngoc Son, Tomas Bata University, Czech Republic, Tel: + 840235 3874216; E-mail: sontn@donga.edu.vn

Received Date: Jun 27, 2018; Accepted Date: Aug 01, 2018; Published Date: Aug 07, 2018

Copyright: (c) 2018 Son TN, This is an open-access article distributed under the terms of the Creative Commons Attribution License, which permits unrestricted use, distribution, and reproduction in any medium, provided the original author and source are credited.

\begin{abstract}
The world's famous economist Herman Daly says that the future of human civilization depends on a new and dynamic economic model - known as a sustainable economy - protecting and preserving the environment. The field that we are depending on it. From there, we need to reorient our economic model so that it goes back to its orbit and thus make life better. Green economy sees deficiencies in the economic development of nations based on contemporary economic models, where a fifth of the population is still living in poverty along with the environmental crisis. According to green economists, the social and environmental crises we are experiencing are not the result of management problems, but of the economic model.
\end{abstract}

Green economy is a progressive branch with a completely new approach, in contrast to traditional economics. However, Green Economy - Economic development model of the post-industrial era is still a fledgling economic theory, a lot of interesting ideas to discuss.

Keywords: Green economy; Contemporary economics; Economic arm progressive; Post-industrial

\section{Introduction}

\section{Green economy concept}

Green economy, not the concept Ecological Economics, not the concept Green economics.

The United Nations Environment Program argues that a green economy is an economy that has improved lives and social equity and significantly reduced the damage to the environment. Environmentally and ecologically speaking. There are many different ways of expressing green economy. Some economists said that [1]:

- Green economy is an economy with low carbon emissions, efficient use of resources and reduction of social inequality.

- Green economy is a clean economy, friendly with the environment, reduce greenhouse gas emissions to mitigate climate change;

- Green economy is an economy that grows in depth, consumes less fuel, enhances eco-industries, renews technology;

- Green economy is a sustainable economic growth, poverty reduction and equity development.

According to individual research, Green Economy is a sustainable economy with innovative technologies in the direction of cleanecological industry, rational use of resources and a renewed consciousness. Decent work and social justice $\left(^{\star}\right)$.

The green economy is a sustainable economy that uses resources efficiently and is accountable to the community, rather than to individual interests. Country or country. However, the difference in the statement $\left({ }^{*}\right)$ that the innovation technology here is not the purchase of modern machinery but an industry that solves the problem of production process is closed on the security. Environmental protection. Not that environmental treatment is by any other agency. In addition, environmental consciousness needs attention [2].

It can be said, the concept and perception of green economy so far is not really clear, there are many different ways and ways to call. Western countries determine the green economy model; Developing countries are moving towards green growth strategies, such as China's transformation of its economic development mode into a green development and building of ecological civilization. The model in Thailand is called "full economy".

Regardless of the approach, one can sum up:

\section{The pillars of green economy}

Green economy consists of three pillars: economic development (issues of economic growth, employment ...); environmental sustainability (reducing carbon and degrading natural resources ...); social cohesion (ensuring the goal of poverty reduction, equality before the opportunities created by green economy, bring fresh environment).

\section{Methodology}

\section{Green research subjects and methodology}

Green economy is a category of economics, so in terms of research methodology is like general economic research:

Research subjects: Macroeconomics studies the choice of each nation for basic economic and social issues such as economic growth; Inflation and unemployment; Import and Export of goods and capital; Distribution of wealth and resources.

Research methodology: It is possible to generalize the methodology of research in economics through four stages as follows: 
When studying economic phenomena, economists use observation methods. Because of the complex economic phenomena, often fluctuations, influenced by many factors subjective and subjective. The economic relationship is very invisible, which we can only speculate through its external market manifestations.

Collection of data for research purposes.

Carry out analysis with appropriate analytical methods.

For each economic event, each economic indicator will have a different analytical approach, using this analytical or other analytical method, or a combination of several analytical methods. Economics, apart from the methods of economic sciences in general, uses particular analytical methods. These are methods of abstraction, removal of unintended factors (fixing these factors) to examine the economic relations between the basic variables directly related to the research event. . Examples are statistical methods, mathematical models, econometrics, general equilibrium methods, and partial balances.

Draw conclusions in comparison with reality, uncover irrational points, make new hypotheses and then test them in practice. This process is repeated until the results are close to reality, when the research process is over.

\section{Theoretical Background}

\section{Scientific background of green economy}

The study of green economics focuses on building a system of tools and methods to capture and overcome economic problems in today's society. For example, given the perceived limitations of the Earth's resources, traditional economic theory considers how scarce it makes sense for value creation. Meanwhile, green economics is the science of redundancy, not of scarcity. Green economics considers issues such as how to grow in a practical, but not infinite, manner and how growth theories lead to current economic goals - motivating consumption. It is very important that this new economic theory should affect "both the poor and the poorest and even the most powerful in society."

Green economics was originally based on the fundamental problems of microeconomics individual preferences or rational human economic behavior, "interdependence" in the category Value and Assignment to the Concept of "Mutual Economic Preferences" [3]. Therefore, the values we create will be of economic value if they reflect respect for the physical world and our connection to the natural world. In other words, economic principles should reflect the relationship between man and the natural world, human desire for a "just enough" life to exist and develop - in opposition to the notion of quantitative and quantitative business purposes, and the sharing of resources between us and between species in a fair and equitable manner to ensure coexistence.

\section{History of green economy}

We can observe that every economic theory is born in a particular context. Traditional economic theory came into being in the 19th century and has been developing since the Great Depression of the 1930 s to deal with the economic problems of that time. In that way, the economic process continued and until the 1960s, people began to realize that ethics in production and business should be rethought. Rachel Carson's book, "The Silent Spring," was written in 1962 as the first warning about the negative effects of economic growth on biodiversity. Since then, the idea of green economic theory has been unveiled.

Green Economy is the first term in 1989 in a report submitted to the UK government by a group of leading economic experts in fog. Where classical and neo-classical economics (Neoclassical economics) have started and is still valid today. With the advent of the term "green economy," the term "green growth" was also known at the 2005 Environmental Development Conference in Seoul, South Korea [4]. Today, the "green growth" model towards a "green economy" has been applied in many developed countries. This is considered a sustainable development trend because it not only stimulates the economy but also enhances the quality of life and protects the environment.

According to the Organization for Economic Co-operation and Development, green growth is a way to achieve economic growth and development while preserving the environment, preventing biodiversity loss and Minimize the unsustainable use of natural resources [5]. The United Nations Economic Commission for Asia and the Pacific (ESCAP) defines green growth as an approach to achieving economic growth for the sake of economic development while ensuring environmental sustainability.

The notion of the United Nations Environment Program and the Organization for Economic Co-operation and Development "green economy" and "green growth" receive [1,5]. "Green Economy" is the economy that can both improve the quality of life and social justice while minimizing the risk of ecological and ecological loss - UNEP ("Green Growth" (GG) is growth retaining natural capital - OECD $[1,5]$.

\section{Data Description}

\section{Contents of green economics on the basis of green economics}

From Figure 1 One of the recent economic theories that emerged was "Green Economics." This economic theory focuses directly on meeting the needs of both people and the environment, for sustainable development. The Green Theory of Green Economics has emerged as a green economy. So, we need to understand what Green Economics is all about:

Green economics is the study of the real-world world of work, human needs, Earth's resources, and the way we harmonize these categories. .

This real world firstly reflects "value of use", not "value of exchange" or money. It represents quality, not quantity, for the benefit of species. It is concerned with the regeneration of individuals, communities and ecosystems - not the accumulation of money or material.

The basic contents of Green Economics are as follows:

Firstly, green economics takes the "value of use" as a goal: money is only seen as a means of reaching its destination, not its "value of exchange"; humanity no longer fits with the mechanisms of money and material accumulation;

Secondly, green economics attaches great importance to quality, not quantity, for the benefit of human life, the species on this Earth;

Thirdly, green economics is aimed at innovation and renewal of individuals, communities and ecosystems. 
Fourthly, green economics focuses on ecological development based on promoting human development with species and systems, ensuring harmony between entities on Earth [6].

Fifth, the state is integrated with the community's innovation networks. The "public" and "private" sectors are transformed so that markets can express social and ecological values.

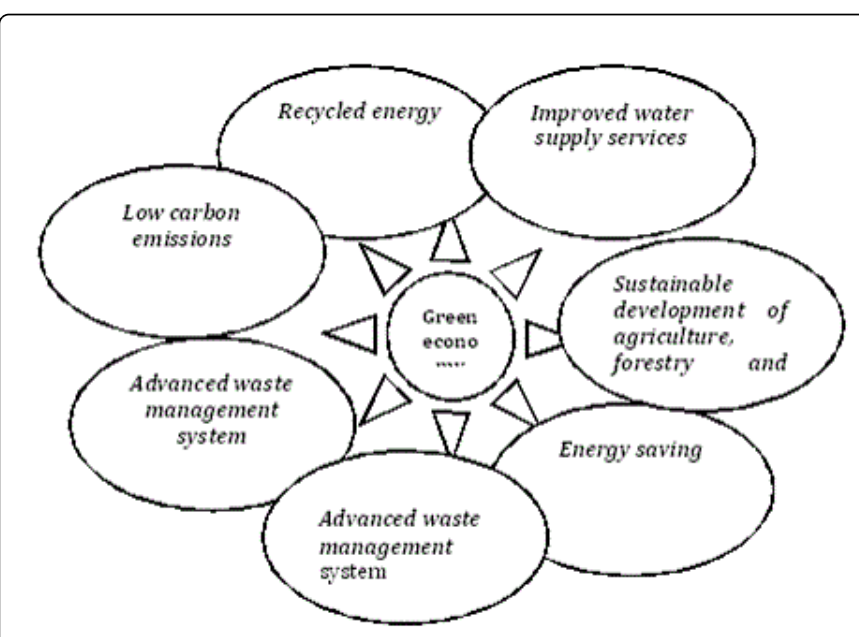

Figure 1: Green economy model under the United Nations Environment Program [1].

\section{How is green economy measured?}

A series of indicators can help to measure the transition towards a green economy. UNEP works with partners such as the OECD and the World Bank to develop a set of indicators from which governments can select appropriate indicators depending on the situation of each country, such as the structure of economy or natural capital. The indicators under development can be roughly divided into the following three groups:

1) Economic indicators: Indicators of investment rates, output ratios and employment in areas that meet sustainability standards, such as green GDP.

2) Environmental indicators: indicators of resource efficiency, pollution at the sectoral level or the whole economy (e.g., energy use / GDP, or water use /GDP).

3) Comprehensive indicators of progress and social welfare: for example, macroeconomic aggregates, including national economic and environmental budgets, or indicators that give full insights. In addition to the narrow definition of GDP per capita.

\section{Results and Discussion}

\section{The current state of development of the economy}

The term "Brown economy": economic development model modern e Chapter is applied mainly in the developing countries. The characteristics of the "brown economy" are the emphasis on GDP growth and per capita income. The growth of "brown economy" based on available resources, economic development means exploitation and depletion of resources, resulting in consequences: the environment is severely damaged; Exhausted resources.
At any time, the activity of all economies has the ultimate goal of creating wealth or prosperity for individuals and societies. However, the concept of wealth and prosperity of the economy is different in different periods. These different notions have created different economic models.

In the industrial age, it was perceived that wealth and economic prosperity were due to the accumulation of capital - money and material. What belongs to the value of use is created, which means that social needs are met, only secondary, or less important than the goal of initial capital accumulation. Over the past two centuries, the pursuit of capitalist accumulation has staged a strong industrialization process. This process actually creates more benefits, material and spiritual wealth, for the human person, but these benefits are distributed unequally. However, material and money growth has now reached the threshold at which it turns out to be more destructive than the production of real estate. Perhaps, the cost of such growth and the limits of growth have not been fully accounted for.

Indeed, traditional economic theory is based on generalized equilibrium models - a system of thousands of equations simultaneously balancing supply and demand, thereby determining the price and quantity of goods and services. This theory assumes that resources are infinite and does not count endless waste. In simple terms, the sources will never go away and pollution will never happen. That means there is no limit to growth.

The fact that there existed and developed over two centuries of traditional economics shows us that this theory puts so much pressure on the natural world and its resources. Economic development mainly focuses on the efficiency and benefits of production, business and service activities, without taking into account the costs of investing to prevent, reduce pollution and protect. Environment Economic growth is now reaching more destructive levels than creating real wealth. Thus, this economic development has brought the world to great economic recession, severe ecological crisis and climate change. If we look at sustainable economic development, the present economic development model is clearly no longer appropriate.

As a result of this economic development, we are facing a number of environmental problems, such as the destruction of the ozone layer, climate change, acid rain, deforestation, overcrowding, soil erosion, desertification, floods, famine, over-fishing, hazardous wastes, lack of clean water, over-exploitation of resources and energy resources there is no possibility of reproduction, etc. According to the green economist Paul Hawken, the social and environmental crises that we are experiencing are not the result of management problems, but by mistake of the economic model.

What the world has been experiencing has forced us to rethink the goal of economic development. Economic development must aim at improving the quality of life, meeting the social needs and ensuring a sustainable environment. Accordingly, we need to lead our lives in a more democratic, effective, fair and responsible way, in which money is only a means of reaching the destination and personal and political and social and ecological, is inseparable.

\section{Trends in green economic development during the revolutionary period 4.0}

It is the perception of that that poses a huge challenge for economists as the world moves into the post-industrial era: Should we "overhaul" the current system, or should "design "A new economic 
model? It is clear that the post-industrial world will demand that economic science pay attention to quality, not quantity, in that both money and material become instrumental to achieving it. Destination simultaneously satisfy the needs of people and the environment.

In the post-industrial society, science and technology have gone through three revolutions to create more food. This is the "genetic revolution" - which some people call the "second green revolution" based on the understanding of the genetic basis of organisms, thus focusing on public development. Biotech to develop new processes and new products in agriculture and medicine. The "information revolution" has helped speed up the transfer and reception of information. The "revolution in biotechnology" is fostering a mix of the best traditional knowledge with modern technology in the fields of biology, energy and materials.

Post-industrial civilization is the result of the third wave of science and technology revolution. Post-industrial civilization is close to agricultural civilization, since high technology is applicable to agricultural situations (e.g., biotechnology can be adapted to social needs, with available resources). And conditions have produced scattered in $\mathrm{n}$ Step largely in agricultural production). At the same time, a traditional agriculture can completely go straight to postindustrial civilization without having to go through all the stages of costly industrialization and causing no small harm. to agriculture, rural areas, farmers and the environment Referral.

Green economics has been gradually established on the basis of a reevaluation of social and environmental change in the world in recent decades. This school of economics goes back to the basics of economics, the study of a family, or more specifically, how to manage a family's assets. It views this earth as a family, which we all belong to and must rely on it. Some developed countries have been transforming from "brown economy" to "green economy" (USA, Japan, China, Korea).

Green economics is a branch of advanced economics with a completely new approach, in contrast to contemporary economics (or traditional economics). If traditional economics is concerned with measuring the effects of economic activity, use mathematical tools to analyze and evaluate economic processes based on the assumptions of economic behavior. 'Homo economicus', green economics is concerned with the evolution of societies according to the history of paleontological development in order to better understand issues such as change climate, not current economic issues and short-term business cycles. That is, economics is a science independent of business management studies.

The "green" people put economics into the Earth as it is and the theories they build derive from that point of view. In fact, green economics is built on the basis of ecological economics, with a focus on democratic accountability for the sake of the environment. Green economics develops these topics in an attempt to simultaneously achieve social justice and environmental justice, as these are two inseparable sides of a whole. It would be short-sighted and misleading if one understands green economics as environmental economics.

\section{Green economy trends for Vietnam's economic development}

Vietnam is beginning to become familiar with green economy trends, with a few green energy projects being piloted. Vietnam is also undertaking a 3R (Reduce, Reuse - Recycle, Recycle - Recycle) project that is internationally well evaluated in theory. Although Vietnam has a policy towards a green industry with low energy consumption, the lowest limit of production is causing environmental pollution, but the implementation is sporadic and not synchronous because of this area. There is no clear green development strategy and planning. This is also a common situation for other parts of the economy. Agriculture is one of the key economic sectors in green development, but also a long-term advantage of Vietnam, but still underdeveloped and at risk of increasingly lagging behind economic sectors. Before that situation, Vietnam has many policies and investment for agriculture, but the implementation is not really effective. Therefore, it is necessary to implement more drastically and at the same time to have a strategy for sustainable agriculture development. Recently, there are many areas to develop plans to develop into ecological areas such as Ninh Thuan [7].

According to the Ministry of Natural Resources and Environment, the current economic downturn is an opportunity for green businesses to grow. In the coming time, the Ministry of Natural Resources and Environment will coordinate with the United Nations Environment Program, the Hans Seidel Foundation (HSF) to provide support to green business development [1].

Considering from an environmental perspective, our country's current growth model is based mainly on the use of many natural resources, environmental impacts and climate change impacts. The process of industrialization and urbanization will lead to a decline in natural resources, and increased $\mathrm{CO}_{2}$ emissions. According to the Energy Information Administration, $\mathrm{CO}_{2}$ emissions will increase from more than 113 million tonnes in 2010 to nearly 471 million tonnes by 2030. Vietnam's economy has grown substantially over the past few years. The "brown economy" is based on resource exploitation with low efficiency, waste generation, environmental pollution and backward technology. Obviously, Vietnam Measures should be taken to transform the growth model in the face of increasingly severe climate change. Turning to a "green economy" platform is the optimal option for sustainable development and poverty reduction in Vietnam.

"In order to restructure the economy, the government sees" green growth and low carbon "as the key driver for sustainable development. Researchers propose a shift towards a greener, eco-friendly economy, limiting pollutant industries, regional economic structures based on ecosystems, commodity development, and services. Environment and clean energy. At the same time, to promote the transfer of environmental technologies, invest in the development of some key green sectors such as organic agriculture, ecotourism, recycling industry, energy At the same time, shaping short-term and long-term difficulties, objectively and objectively, to soon change the awareness, establish a legal corridor, open the road for Green economy, especially the awareness of moving to a green economy model, will bring longterm economic benefits to the economy of the country.

Based on international experience, Vietnam's Green Growth Strategy has been developed and, with the support of the international community, the transition to a green economy in Vietnam has taken place [8]. The first step was to build and put into operation many small hydropower projects, wind power, using gas at the landfill to generate electricity, using waste nylon in construction, pressure Clean development mechanism, use of wind energy, solar energy, biogas in animal husbandry, straw by-products, organic fertilizer, forest plantation and regeneration, control to limit deforestation.

In 2011, the Government set up the Green Growth Strategy Framework. The overall objective of the proposed strategic framework is that Vietnam establishes a basic economic, social, scientific and technological basis for achieving green growth, low carbon, and 
Citation: Son TN (2018) Green Economy-Inevitable Economy of the Industrial Revolutionary Period 4.0 . J Glob Econ 6: 300 . doi: $10.4172 / 2375-4389.1000300$

Page 5 of 5

building economic structures. On the economic, social and environmental front, more and more green technologies are being introduced, creating green lifestyles and sustainable consumption [9]. Specific objectives up to 2020 are set out, focusing on three main goals for reforming the growth model and restructure the economy: (i) reducing greenhouse gas emissions and increasing use clean energy, renewable energy; (ii) green production; (iii) greening the way of life and promoting sustainable consumption. Vision to 2050, Vietnam will establish adequate material, technical, human and institutional resources to disseminate and implement green growth practices. The Strategy also identifies a number of quantitative targets such as energy savings; use renewable energy, reduce emissions in agriculture; cleaner production; the percentage of investment for the environment; Green GDP. Selected solutions and policy options such as economic, technological and financial restructuring; Organizing, directing, supervising, handling violations, integrating ... will be implemented. The Green Growth Strategy Framework will open the door to the development of "green economy" in Vietnam [10].

\section{Conclusion}

We cannot deny the breakthroughs that the economy has relied on for the "brown economy" of fossil fuel energy that has been brought to humanity for more than two centuries. So far the question of whether the "green economy" model has led to success in economic growth as the "brown economy" that developed countries have experienced or not? There is no conclusion. Although many countries in the world have been racing in the process of "change blood" from the model "brown economy" to "green economy"; However, in order to evaluate the effectiveness of these models, we need more verifiable studies. But it is certain that production that pays too much attention to environmental protection will reduce economic efficiency, but only economic development without regard for the environment will cause humanity to suffer heavy consequences. social and environmental crisis.
Green economy ", though not yet clearly defined and fully understood, is becoming a worldwide trend that can be applied to all economies in response to crises. Present and prevent possible future crises. The shift to green economy is seen as a strategy for countries to move towards sustainable development; in which economic development, social development and environmental protection are balanced and harmonious. In order to develop the green economy, countries should base themselves on the economic characteristics, natural resources, culture and society and development level to determine the specific objectives, directions, tissue and approach.

\section{References}

1. UNEP (2011), Towards a Green Economy: Pathways to Sustainable Development and Poverty Eradication - A Synthesis for Policy Market . Nairobi, Kenya.

2. Green Economics. Investopedia.

3. Kennet M (2007) Green Economics: An Introduction to Progressive Economics. Harvard College Economics Review.

4. Dung VA (2012) T antennas green economy in Korea. topic of scientific research, economic University, Vietnam.

5. OECD (2011), Toward Green Growth, The OECD Green Growth Strategy: A Lens for Examining Growth.

6. Khanh PV (2010) Green Economy Development. Nhan Dan Newspaper.

7. Nguyen KNTKT (2015) The development trend of green economy in the world. J Soc Sci Vietnam.

8. Nguyen QT (2012) Green Economy in the Innovation Model of Growth and Restructuring in Vietnam Economy. J World Econ Polit Issues.

9. Green Audit. Spectro analytical lab ltd.

10. Burniaux JM, Chateau J (2009) The Economics of Climate Change Mitigation: How to Develop the Global Action-Cost-Effective Manner, OECD Economics Department Working Papers, Paris. 